\title{
Action Research of In-Service Training for Reception Year Teachers of North West Department of Education; South Africa
}

\author{
Soane Joyce Mohapi \\ Manager Centre for Continuous Professional \\ Teacher Development and Community Education and Training \\ College of Education, University of South Africa \\ mohapsj@unisa.ac.za
}

Doi:10.5901/mjss.2014.v5n1p97

Abtract

The paper reports on the results on one year continuous professional teacher development program conducted for 383 reception year teachers. Questionnaires and document analysis were use to collect data. Questions looked at teaching experience, qualification, training support, overcrowding, assessment and content knowledge. A sample of 30 teachers from the population of 383 was selected and observed while teaching in their respective classrooms. The study revealed many challenges experienced by reception year teachers; such as lack of resources, support from school management team (SMT) and teachers' lack of content knowledge. While these teachers have professional teachers' qualification, they do not have a qualification in the teaching of reception year class. The study provides insights on how reception year teachers may be assisted in handling reception year class.

Keywords: Teacher in-service training, Grade R, Classroom practices

\section{Introduction and Background}

In keeping with the trust of transformation in education, the white paper 5 on early Childhood Development (2001) and the National Curriculum Statement both aspire to provide quality grade R Programme to many South African learners aged six. Reception year class receives children from Kindergarten and prepares them for Grade one. There is evidence research that teaching in reception year class remains a challenge for teachers. The study is aimed at revealing challenges revealed by the in-service conducted in the sample province. Integrated quality management system encourages teachers to participate in their own development by conducting self assessment, at certain point this is not done properly.

In-service teacher training where teachers are involved may improve teaching. In the reception year there is a strong emphasis that learners should learn through play. This suggests that teachers need to understand how learning through play is suited to develop learning abilities of reception year learners. In the past, in-service training that is aimed at teacher development was unsuccessful because it did not address contextual matters that create the conditions to facilitate the learning of adults (Hopkins; Ainscow; West, 1994). The following reasons are sided as failure of in-service training:

- One-shot workshops are widespread but are ineffective.

- Topics are frequently selected by people other than those for whom the in-service training is provided.

- Follow-up support for ideas and practices introduced during in-service programmes occurs only in a very small minority of cases.

- Follow-up evaluation occurs infrequently.

- In-service programmes rarely address the individual needs and concerns of participants.

- The majority of programmes involve teachers from many different schools, but there is no recognition of the differential impact of positive and negative factors within the system to which they must return.

- There is a profound lack of any conceptual basis in the planning and implementation of in-service programmes that would ensure their effectiveness. (Fullan, 1991

The above reasons indicate that in-service initiatives were poorly conceptualized, insensitive to the concerns of individual teacher and made little effort to help teachers to relate their learning experiences to their usual workplace conditions. Teachers need professional development that extends far beyond the one-shot workshop (Darling - 
Hammond; Mc Langhling, 1995) (Saylor; Kehrhahn, 2003). Teachers need opportunities to learn how to question, analyze and change instructions to teach challenging content.

From this discussion, it is evident that the benefits of in-service training include: the promotion of professional development, improvement of teachers' performance and change in classroom pedagogy (Ulker; Tas, 2009)

\section{Theoretical Framework}

The study used constructivism approach as a framework to understand the challenges faced by Reception year teachers in order to present in-service training that can improve their classroom practice. Constructivism is a concept situated in the ambiguity that arises among stakeholders in education settings, it assumes that people know and understand in unique ways and create their own new knowledge. It assumes that reception year teachers in the study will create their own new knowledge during the in-service training. The basic ontological assumption of constructivism is relativism that is it assumes that human sense-making is a process that systematizes experience so as to render it understandable. As paradigm it places greater emphasis on the child's development and understanding of more general social processes and relationship

Reception year teachers need to understand children development, the study hope to reveal solutions that will help teachers to improve their classroom practices.

\section{Research Methods}

Mixed methods were used. Questionnaires were administered to 383 reception year teachers. It consisted of both openended and closed-ended questions. This was done to ensure that the participants respond to similar questions and also to receive in-depth information regarding teaching in the reception year.

\section{Action Research}

In- service training conducted was designed for teachers whose professional preparation was below the requirements of National Curriculum Statement (NCS), it was designed to increase their knowledge and sharpen their skills. Action research is the appropriate design, because after every step of the process teachers were consulted. Action research involves systematic investigation of new actions by practitioners in order to improve their effectiveness (Gall; Gall ; Borg, 2005). All 383 participants were active members in the research process. Action research is informal, qualitative, formative, subjective, interpretive, reflective and experiential model of inquiry in which all individuals involved in the study are contributing participants (Hopkins, 1993).

Stephen Kemmis et al (2002) have developed a simple model of the cyclical nature of the typical action research process. According to him each cycle has four steps: plan, act, observe and reflect. For the purpose of this study teachers were part of the planning stage, involved in the activities designed for the program, the researcher observe teachers and reflection was conducted at the end. Susman (1983) distinguished five steps of action research model: Diagnosing, action planning, taking action, evaluating and specifying learning:

Figure 1: Detailed Action Research Model

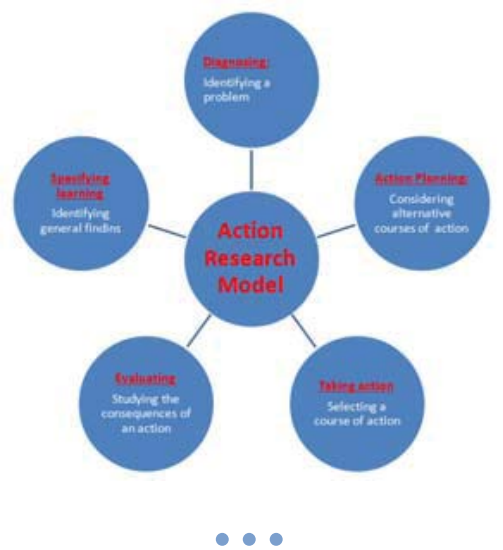


Detailed Action Research model (Adapted from Susman 1983)

In terms of the model above, the researcher together with the teachers identified the problem and plan together strategies to solve their challenges, relevant course material were designed for in-service training, and 383 teachers were trained for 15 days. Post assessment was conducted to evaluate the training

\section{Sampling}

383 reception year teachers in five districts of the North West Provincial Department of Education were purposively selected. The desired population was all teachers who had taught and are still teaching a reception year class. From this sample 30 were randomly selected for classroom observation.

\section{Data Collection}

$99 \%$ of respondents were females and only $1 \%$ was males. It should be pointed out that the purpose of the study was not to find the relationship between males and females and for this reason gender was not considered for analysis. However, it is interesting to note that the overwhelming majority of reception year teachers are females.

\section{Data Analysis}

Data was analyzed using the Statistical Package for the Social Sciences (SPSS). Teachers' professional needs were analyzed and possible solutions to problems that teachers encounter in their teaching in the reception year class. Frequency distributions and means were computed.

\section{Results and discussions}

The move by the Department of education to include reception year class in all schools demand that the reception year teacher be well equipped to handle all Grades in the Foundation phase (R-3).

Table 1: Teaching experience

\begin{tabular}{|c|l|c|c|}
\hline \multicolumn{2}{|c|}{} & Frequency & Percent \\
\hline \multirow{4}{*}{ Valid } & $0-1$ year & 109 & 28.4 \\
\cline { 2 - 4 } & 2-3 years & 31 & 8.1 \\
\cline { 2 - 4 } & 4-5 years & 28 & 7.5 \\
\cline { 2 - 4 } & 6-7 years & 12 & 3.1 \\
\cline { 2 - 4 } & 8-9 years & 12 & 3.1 \\
\cline { 2 - 4 } & 10 and more years & 191 & 49.8 \\
\cline { 2 - 4 } & Total & 383 & 100 \\
\hline
\end{tabular}

The profile of teachers who participated in this study shows that majority $191(49.8 \%)$ had more ten years in the teaching profession. This indicated that they have a vast amount of experience. It should be pointed out that this data could give a wrong impression; as most of the teachers were not trained in the teaching of reception year class, therefore their experience is not relevant in the reception year class. In addition, the data shows that most teachers are in the late 40s and 50s could mean that they are not well conversant with the new methods of teaching reception year class. It is also interesting to note that some of the participants will soon be retiring so this poses a question of sustainability and investment.

Table 2: Support

\begin{tabular}{|cc|c|c|}
\hline & & Frequency & Percent \\
\hline \multirow{3}{*}{ Valid } & Yes & 358 & 93.5 \\
& No & 24 & 6.3 \\
& Total & 382 & 99.7
\end{tabular}




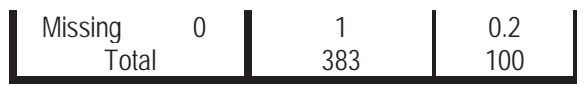

Lack of support from the subject advisors and school management team was cited as one of the problem that teachers encounter in their teaching. Majority 353 (93.5) of the teachers indicated that they need support from the subject advisors and school management team.

As Glover\& Law, 1996 pointed out, professional development strategies must take into account the importance of support and the time required to implement improvement. This suggests that if teachers could be given support that could enhance implementation. Teachers need to be given enough support for them to be able to carry out their duties successfully (Guskey, 2002).

Table 3: Qualification

\begin{tabular}{|c|c|c|c|}
\hline & Frequency & Percent \\
\hline \multirow[t]{5}{*}{ Valid } & Diploma in education & 256 & 66.8 \\
\hline & Advance certificate in education & 20 & 5.2 \\
\hline & BEd degree & 104 & 27.2 \\
\hline & Other & 3 & 0.8 \\
\hline & Total & 383 & 100 \\
\hline
\end{tabular}

It is evident from the data that most $256(66.8 \%)$ of the reception year teachers have Diploma in Education and 104 (27.2\%) Bachelor of Education degree. Only few $20(5.2 \%$ and $3(0.8 \%)$ have advanced certificate and other qualification. It should be mentioned that the above results could be misleading as most of the teachers, even though they have formal training after grade 12 , the training they received was not related to reception year teaching. Therefore it did not equip them with the necessary skills and expertise needed to teach reception year learners.

\section{Training}

The results further showed that majority $323(84.3 \%)$ indicated that they received no training in reception year teaching. Only $60(15.7 \% \%)$ received training. As the above table 3 suggests teachers are qualified but not as reception year teachers. 383 teachers teaching reception year did not undergo a specialized training for reception year teaching. Although they are qualified as Foundation Phase teachers, reception year class was not part of Foundation phase. It is evident that in most schools teachers use an "instructional" approach to teaching and learning in reception year class. Learners are found seated in tables doing very formal activities. Learners in reception year need to learn informally through play (Davin \& Van Staden, 2004). They further argue that learners can acquire knowledge, skills and attitude through play based activities designed by the teachers.

\section{Assessment}

Assessment is still a challenge in reception year as teachers do not seem to understand how formal assessment can be done in an informal situation. Assessment is an essential feature of the teaching and learning process and should be integrated into it on a continuous basis. This implies that assessment is used to determine whether the learners' level of knowledge and performance accurately reflects the specific outcomes that the learning programme expects of them. Therefore, the teacher needs to carefully plan his/her assessment to ensure that the assessment activities will reflect the type of evidence to be collected, competencies assessed, assessment methods and instruments and the logistical arrangements that should be in place.

\section{Overcrowded classroom}

The results also indicated that teachers do not have enough space for different activities in class. This problem is exacerbated by the overcrowded classrooms that teachers are faced with. For example there is no space for fantasy area, art area and book area. Proper planning of the classroom is very important for successful teaching in reception year (Davin \& Van Staden, 2004). This suggests that learners require enough and well planned space in order to learn 
through play.

Table 4: Content knowledge

\begin{tabular}{|cl|c|c|}
\hline & & Frequency & Percent \\
\hline Valid & Good & 63 & 16.4 \\
& Satisfactory & 61 & 16 \\
& Not sure & 258 & 67.4 \\
& Total & 386 & 99.8 \\
\multirow{2}{*}{ Missing } & 0 & 1 & 0.2 \\
& Total & 383 & 100.0 \\
\hline
\end{tabular}

The majority $258(67.4 \%)$ of participants indicated that they are not sure of their level of the content knowledge of the Learning programme that they were teaching. This is an indication that content knowledge of different Learning programme (Life skills, Mathematics and Literacy) is still a challenge to teachers. Having teachers with little content knowledge can have harmful effect on learner achievement. Desomone, Smith; Ueno, 2006 suggest that the level of teacher preparedness, both in subject matter knowledge and pedagogical knowledge is associated with higher learner achievement.

\section{Recommendations.}

Based on these findings, the study recommends three steps to be considered when conducting teacher in-service training of teachers:

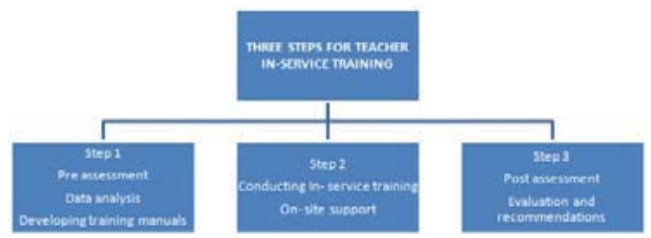

In the first step teachers' knowledge will be assessed ahead of the in-service training. The data collected will inform the researcher to design appropriate training material.

In the second step is where actual training is taking place and verification through on site support to determine the effectiveness of the training.

Step three is about evaluating the effectiveness of the in-service training and proposal for future intervention is made based on the results from post assessment.

\section{References}

Altricher, H. , Kemmis, S., Mc. Taggart R. \& Skernt O. 2002. "The concept of action research", learning organization, Vol 9 3pp 125-137 Darling- Hammond \& McLaughlin, MW. 1995. Policies that support professional development in an era of reform. Phi Delta Kappan, 76(8), 597-604.

Davin, RJ \& Van Staden, CJS. 2004. The reception year: Learning Through Play. Johannesburg: Heinemann Publishers.

Department of Education 2000. Norms and Standards for Educators. Pretoria: Government Printers.

Department of Education 2002. Revised National Curriculum Statement Grades R-9 (Schools): Policy. Pretoria: Government Printers Department of Education 2003. National Curriculum Statement. Grades 10-12 (General). South Africa: Government printers.

Department of Education 2004. Curriculum 2005. Revised National Curriculum Statement, Grades 7-9(Schools). South Africa: Government Printers.

Department of Education 2007. The National Policy Framework for Teacher Education and Development in South Africa. Pretoria: Government Printers.

Desimone, LM. Smith TM. \& Ueno K. 2006. Are teachers who need sustained content-focused professional development getting it? An Administrator's Dilemma. Educational Administration Quarterly, 42(2): 179-215

Fullan, MG. 1991. The new meaning of educational change. London: Cassell. 
Gall, JP., Gall MD \& Borg, WR 2005. Applying education research, a practical guide. Boston: Pearson Education, INC Glover, D \& Law S. (1996). Managing Professional Development in Education. London: Kogan Page

Guskey, TR. 2002. Professional Development and Teacher Change. Teachers and teaching: Theory and practice, 8,381-391. Hopkins, D., Ainscow M. \& West M. 1994. School Improvement in an era of change. New York: Redwood Books.

Saylor, P. \& Kehrhahn. 2003. Teachers skills get an upgrade. Journal of Staff Development. 24(1). 48.

Susman, GI. 1983. "Action research: a Sociotechnical systems perspectives" Ed.G Morgan. London: Sage publication. 95-113. 